\title{
Cultural Determinants Within the Design Set Up of Kindergarten and Preschool Interiors: Assessment of Four Typologies in Terms of Their Spatial Formation
}

\author{
Anaokulu ve Kreşlerin Iç Mekan Tasarım Kurgusu Içerisindeki Kültürel Belirleyiciler; \\ Mekansal Oluşumlarının Dört Tipolojisi Üzerinde Analizi
}

Meryem YALÇIN, ${ }^{1}$ Ayşe Müge BOZDAYI, ${ }^{1}$ Mehmet Hakan ERTEK ${ }^{2}$

The dynamic and complex nature of children's sense of physical environment (Lim, Barton, 2010) with respect to the location of the space concerning cultural conditions, relations, and parameters direct design criteria to meet pedagogic, physiologic, and biological needs and requirements of the children in the preschool interiors. This enquiry has grown out of the desire to examine the parameters, cultural aspects, dimensions, or contexts affecting the built environment in the preschool interiors where children spend most of their time out of their home. Conceptual components affecting the interior space of pre-school education centers are identified and based on literature review, interviews, surveys, observational data, and statistical concepts such as education models, socio-economic conditions, appreciation of adults, child-teacher-parent relations, and location related to culture. These contextual connections and relations with the interior environment shaped the body of the study. Based on the above-mentioned items, a research questionnaire was used in centers located in the Çankaya and Çayyolu regions of Ankara. Subjects were randomly selected from among the parents of these preschools' students. Accordingly, the research questionnaire was directed to a total of 200 respondents from 15 pre-school centers; these preschool education centers are the ones applying the Montessori education model, providing education in English and highlighting features like physical space comfort, etc. Those centers have maintained their corporate identity thanks to the above-counted features. Consequently, data has shown that the education model, socio-economic conditions, appreciation of adults, child-teacher-parent relations, and location have an indirect and direct bearing on parent perception of the preschool centers which affects the centers' formation of Interior spatial design.

Keywords: Culture; preschool interiors; spatial design set-up.

Anaokullarının mekansal oluşumu,çocuğun, değişen fiziksel çevre koşullarına bağlı olarak gelişen karmaşık ve dinamik bir etkileşim sürecidir. Farklı kültürel koşullar, ilişkiler ve parametreler bu mekanlarda pedagojik, psikolojik ve biyolojik gereksinimleri doğurmaktadır. Bu çalışmanın amacı çocukların ev dışında en çok vakit geçirdiği ana okullarının mekan oluşumunda etkili olan kültürel parametrelerin, boyut ve bağlamını ortaya koymaktır. Literatür taraması, mülakat ve istatistiksel araştırma sonucunda elde edilen verilere göre; Eğitim Modeli, Socio-Ekonomik koşullar, Yetişkin ölçütü, Çocuk-Eğitim-Ebeveyn İlişkileri ve Konum Kültür ile ilişkilidir. Bu kavramsal iliş̧kiler çalışmanın gövdesini oluşturmaktadır. Yukarıda belirtilen unsurlarla ilişkili olarak Ankara Çankaya ve Çayyolu semtlerinde yer alan anaokullarında anket çalışması yapılmıştır. Anketler, bahsi geçen bölgede 15 Anaokulunda 200 katılımcıya uygulanmıştır. Anaokulları Montessori eğitim modeli uygulayan, İngilizce eğitim veren, fiziksel şartları ile öne çıkan ve bir markanın zinciri olmak üzere sınıflandırılmıştır. Sonuç olarak, yapılan farklı sınıflandırmalara bağlı olarak, değişen kültürel parametrelerin Anaokullarının mekansal oluşumunda direk ve dolaylı etkisi bulunmaktadır.

Anahtar sözcükler: Kültür; anaokulu iç mekanları; mekansal tasarım kurgusu.

'Tobb Economy and Technology University, Faculty of Fine Arts, Design and Architecture, Interior Architecture and Environmental Design, Ankara, Turkey ${ }^{2}$ Hacettepe University, Fine Arts Faculty, Interior Architecture and Environmental Design Department, Ankara, Turkey 


\section{Introduction}

Various academic areas such as psychology, pedagogy, environmental disciplines and design made the emphasis on this issue. However, relatively limited attention has been paid to the inquiry of the cultural context of physical environment-child interaction from the educational community and designers. The components of a learning system are targets, physical environments, and social texture, learning units, methods and educator. Physical environments cover all these components within its scope (Margolin, Margolin \&Margolin, 2002; Baykal, 2004; Moore, 1995; Sanoff, 1995; Weinstein, David, 1987; Altman, 1980). There is an inevitable correlation between educational concepts and interior space formation taking its source from the components herein. The effect of the spatial attribute on learning environments has not been researched directly as far as is known. Spatial research has focused on spatial knowing, the social and cultural variables acting between the children and their environment and is related with the possibilities presented to the children by the environment (Yaneva; 2009; Guy, 2000; Farver, 1999; Gaskins, 1999). Children needs a physical environment presenting rich opportunities where he/she can discover, experience, stimulate their senses (Day, Midbjer, 2007; Stankovic, Milojkovic\& Tanic, 2006; Sanoff, 1995, Moore et al.., 1995, 1994, 1987). In addition, the value given to and opportunities provided to the children by the space present cultural, economic and social conditions of the community in question (Çukur, Delice, 2011; Cohen, Trostle, 1990; Altman, 1980). Therefore, pre-school interior spaces where the children spend most of their time out of their homes should overlap with educational activities and be designed in accordance with culture, psychology, improvement, identity, knowledge and skills of the children and should have its spatial statement as a whole and manifest itself (Read, 2007; Kounin, Sherman, 2001; Abbot, 2001; Moore, 1995; Gump, 1987).

So, "Culture" within a preschool interior design setup is a phenomenon including a very wide and abstract range of concepts. Clearing these concepts up shall assists clearing how subheadings of the culture interrelate as well as its components and propositions, moreover it shall ease understanding the relation with the environment constructed (Kimbel, 2011; 2012; Guy, 2002; Rapoport, 2001:102). Research conducted on the basis of this understanding explains child-culture-space interaction in pre-school interior design where Environment Psychology, Education and Design sciences intersects.

Regarding various dynamic and complex dimensions of children's sense of physical environment. It is greatly significant to create ideal contexts of interior environment which stimulates the learning and development process of children (Stankovic, Milojkovic, Tanic, 2006; Gür, 2004; Dudek 2000, 2001; Sanoff, 1993; Bozdayi, 1988; Weinstein and David 1987; Moore, 1987). Various academic areas such as psychology, pedagogy, environmental and design disciplines made the emphasis on this issue. However, relatively limited attention has been paid to the inquiry of the cultural context of physical environmentchild interaction from the educational community and designers. This study aims to demonstrate and structure on the basis of point out this view gained in the scope of culture-child-space relation, impacts of conditions brought by contemporary culture on education spaces which should be evaluated, include and correlate many sub-headings as such;

In this framework, items identified as "specific to the culture" within design set-up of pre-school interior spaces are location, socio-economic factors, education system, child-environment relations (psycho-social indicators), child-parent-trainer relations and legal arrangements. All of these headings are subcomponents affecting design setup and should be considerate as a whole on the formation of physical characteristics in accordance with socio-cultural parameters in preschool interiors.

\section{Conceptual Background; "Culture" with in the Design Set-up of Pre-school Interior Spaces}

Within the scope of design set-up, "culture" should be in accordance with the physical components of the environment and should support them. Social variables are cultural sub-components of the space to be designed. Each space has specific cultural components which define complementary physical and functional constituents within its design set-up. Therefore, first segmentation process shall be extremely beneficial during this period (Han et al.,2008; Bell, 2006; Rapoport, 2001:102 Gustafson, 2001). In the design process of pre-school education centres. Grounded on this knowledge components cultural parameters affecting the spatial formation of preschool interiors as such: Socio-economic factors: defined by the expectations and needs arisen due to social environment where the child develops, traditionscustoms, education level, family structure and associated factors; Location: as socio-economic, climatic and geographical conditions; Educational Model: as educational activities, activity corners, facilities, philosophy, objectives and principles; Legal Arrangements: mandatory conditions brought by education, personnel, objective, principle, objective and responsibilities; childenvironment relation: child development and psychology and perception of physical environment, as well as spatial needs such as personal space, privacy and place attachment; child-parent-trainer relations: in the scope of child development and education this relationship is analysed in order to determine its reciprocal effect in creation of physical environment and is evaluated within pre-school 
space design which as a result is correlated with interior space items. These items are the parts of a whole that affect each other. On account of corresponding such controversial cultural items affecting creation of pre-school learning spaces are explained in details as following;

\section{Socio-Economic Factors}

Factors constituting the culture of the community, such as environmental, social-economic and cultural issues represent comprehensive and complex issue covering many factors like climate, settlement, consumption resources, technology, economy, policy, religion, traditions, family structure, customs (Read, 2007; Moore, 2002; Rapaport, 2000). All these factors have impact on community as the community affects family and the family affects children and their environment. In addition, component groups which become more specific in time, such as world views, values, images, norms, life-styles and activity systems present the culture's expression on the design process (Rapaport, 2001:104). Such is the case of old cultures where ideas may be obtained about their ideals and expectations as a result of analyzing their school buildings. Likewise, to gain information on goals and values of present communities their education structures may be turned to (Moore, 2002; Dudek, 2000; Cohen, Trostle, 1990; Farver, 1999).

\section{Location}

Location has direct and indirect bearing with spatial formation, where all design set-up gains function as to be in relation with each other. Yet location of pre-school education centre defines sociocultural, physical, economic parameters (Faber, \&Kuo, 2006; Gustafson, 2001). As it was stated before that the space must contain and relate

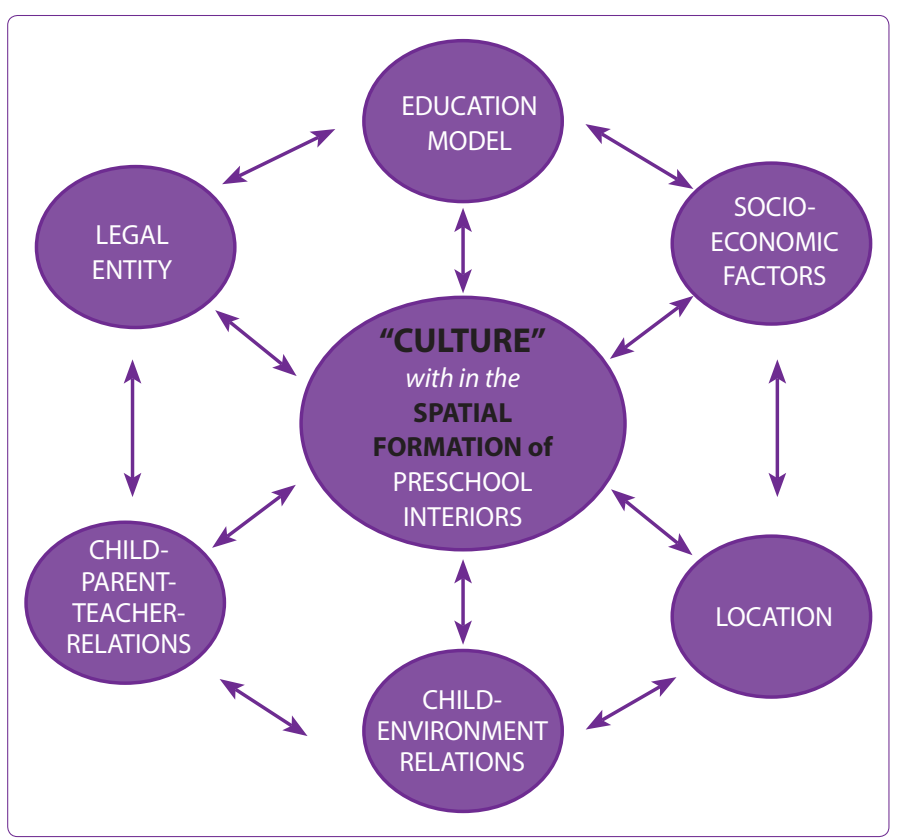

Figure 1. Conceptual items affecting creation of physical features in design of pre-school educational spaces (Yalcin, 2011). many components of the space including even the socioeconomic parameters. Location of the building defines the climatic meaning ecologic, geographical and economic roles of the culture. In other words, though the relations between the space and location are not clear, it may be interpreted that they reveal the "symbolic" role of cultural anthropology and ethnography, as well as "economic" role of ecological anthropology (Rapaport, 2000:85). In order to get an idea of the place establishment within the urban structure the social and economic conditions, site data, natural and artificial environment features must be considered. Understanding the socio-cultural parameters of the region where the establishment is located shall facilitate evoking place attachment within the context of environments designed for children and increase self-esteem and familiarity senses on children (Vojislav et al., 2013; Lim, Barton, 2010; Gibson, 1986). In addition, the site selected for the physical space and environmental arrangement related with selection of location defines design criteria on the basis of its position, as well as its quality and quantity features and relations with natural and artificial environment (Derr, 2002; Day, 2002; 1990; Moore, 1987).

\section{Education System}

Although education is structured over universal concept, impacts of cultural differences within the community on education are inevitable (Feldman, 2007; Gump, 1987). Designing educational spaces require knowledge about education-learning programs. Arrangement of education programs with respect to its four dimensions shall have positive contributions to the education processes. That is, the space designed should be suitable in order to realize targets and objectives of education, increase the materialization of its content, implementation of education curriculum and healthy application of the evaluation (Bell, 2006; Gür\& Zorlu, 2002;Dudek, 2000; 2001; Rivlin, Wolfe, 1985).

In the field of early childhood education, it is suggested that the cultural context of a program be considered in designing early childhood education curriculum in addition to the developmental and the knowledge dimensions (Spencer \& Blades, 2006; Kyle et al., 2004; Gaskins, 1999; Farver, 1999; Spodek, 1986). Education medium of pre-school education entities directly or indirectly affect systematic learning, formation of specific objectives and gaining on the basis of child development area and child-familyteacher-director communication. Impacts and benefits of physical spaces in terms of child development should be explained to the parents at entities affiliated and not affiliated to the Ministry of National Education (Bell, 2006; Maxwell, 2003). This way the parents would incline towards thinking about the selection criteria and the establishment owners and the trainers would incline towards consulting to an expert regarding the develop- 
ment and needs of a preschool children while designing a preschool interior. Another way of dissemination may be consideration of pre-school children and parents education within the same program (Yalcin, 2011).

\section{Child-Environment Relationship}

It is asserted by many psychologist, sociologist and environmental designers that perception-cognition-behaviour process of children is affected due to their experiences and features of the physical environment where they live in the scope of inter-disciplinary knowledge, such as Environmental Psychology, Architectural Psychology and Ecological Psychology (Day, Midbjer, 2007; Uysal, 2006; Gür, Zorlu, 2002, Bozdayı, 1988; Altman, 1980). During space design process for children, their developmental characteristics, psychology, physiology, education, happiness, environmental perception and point of view should be well evaluated (Yaneva, 2009; Day\& Midbjer, 2007; Stankovic \& Stojic, 2007; Bell, 2006; Dudek, 2000; 1996;). During this period when senses are used intensely the child tries to understand, perceive and explain the meaning of theirs and their environment on the basis of perceptions. When the children experiences their environment, acts, uses sense, tries to respond questions, thinks, and improves understanding skills. However, characteristics of the development are related with the environmental factors (Read, 2007; Korpela, 2002; Old, 2001;). In other words, the space and individual/student are all parts of a whole and affect each other. On the basis of hermeneuticphenomenological point of view, Heideger supports that the space is not only a thing perceived or apprehended, but also it is the shape of presence by highlighting the reality of our existence in spatial sense instead of the time when we exist within the space (Spencer \& Blades, 2006; Kyle et al., 2004; Korpela, 2002). Each individual desires to live in a space being a reflection of his/her personality, sense and feelings, in short, himself/herself. This can be possible at spaces where children can establish integration, reflecting their or the areas where children can personalize and adopt. When this requirement is analysed within preschool education centres; children are not only specific to the personal/special spaces; but also social/special spaces where they can share with their peers/friends should also be taken into consideration (Türe, Karaküçük, 2011). In this context another important issue within the childenvironment relation is to understand Place/Self Identity which conveys a deeper understanding to the cultural components of children's connection of their environment.

\section{Place/Self Identity}

Place identity is again a cultural issue which embraces the physical, social, cultural environment and Self-identity are subtle issues for children and characterised by memories, attitudes, values, thoughts, meanings and behaviour.
Covered social and cultural processes and place identity are involved in the development of self-identity. Objects, relations and the surrounding physical world shape individuals and vice versa (Han et al., 2008; Abbot, 2001; Guy, 2000; Proshanskyet al., 1995, 1983, 1979; Proshansky, 1987; Proshansky and Fabian, 1978). Therefore, in addition to children developmental features having impact on creation of education models arisen due to provision of ideal conditions in accordance with community needs, effects of socio-economic and cultural components are extreme (Margolin \& Margolin, 2002; Abbot, 2001; Farver, 1999; Spodek, 1986; Gibson, 1986;). Primarily concentrating on Education, the centres aim not only at the formation of behavioural change of the children, but also at the identification of requirements on the basis of sociocultural features of the environment besides considering spatial behaviours of children. Whereas, behaviour covers many components, such as culture, social values, position, family structure, education and social interaction (Moore, 1987). In this context, the design should respond to "culture" in other words, be unique to the "culture" (Rapaport, 2004:1).

Moreover, Concept of identification with some place in space is considered as a kind of identification representing a "factor in the substructure of personal identity, which in a larger context consisting also of the knowledge of physical world in which the person lives. Such knowledge consists of memories, ideas, attitudes, values, preferences, meanings and concepts of behaviours and experiences which refer to the wide complex of physical environment and defines, day in day out, the existence of every human being". In the basics of such relation with physical environment lies the knowledge of some interior space in one's past, experienced in a certain environment and ambiance. In that way, the past of the person becomes the part of some place, and physical space with what constitutes it and what is set inside of it and makes it an environmental unit, becomes an instrument that fulfils biological, social and cultural needs of the person using it (Proshanskyet al., 1995, 1983, 1979; Proshansky, 1987; Proshanskyand Fabian, 1978).

\section{Child-Parent-Trainer Relations}

Pre-schools should be in effort to create education programs and spaces integrated with education programs in the framework of needs, perceptions and recommendations of living components, such as teachers, students, parents and directors (Yaneva; 2008; Dudek, 2005; 2000; Moore at al., 1994, 1995, Sanoff, 1993). Children are secret customers directing design of spaces where they live. The main decision-makers are parents, establishment directors, educators and designers (Dudek, 2005, 2000). Attitude, knowledge and expectations of above stated individ- 
uals affect design process of any pre-school entity. Parents and educators' description of the ideal learning environment provides designers with significant insight into design priorities for the physical environment of early childhood centres. Descriptions about the key spatial qualities are emphasized. This is in line with Moore's (1987).

\section{Legal Regulations}

Majority of pre-school entities act in accordance with the governmental regulations both in our country and the world. Principles and procedures regarding management, training, foundation, tasks and functioning of public and private pre-school institutions are arranged in the scope of regulations. Each country has "pre-school education regulations" affiliated to educational public enterprises, where objectives and principles, functioning, philosophy and education process of pre-school education system are explained. These rules arranged with respect to the culture, socio-economic parameters, expectations and needs of countries explain overall education system and other issues covered by this system, as well as arrangement of physical space, utilization principles, furniture-equipment and features of educational tools (Kounin, \& Sherman, 2001; Koçak, 2001, Moore, 1994; Spodek, 1986; Rivlin, Wolfe, 1985).

Derived from this knowledge a cognitive design model have been established and examined Emphasizing cultural items, a proposal interior design model of preschool has been established drawn upon above dimensions and details.

\section{Theoretical Framework that Guides the Study}

Building upon multidimensional children-physical environment interaction, this study illuminates and analyses cultural items within the process of generating interior spaces for preschool children. This conceptual model describes the direct and indirect relations between culture, conceptual items and physical environment; Sub-components of culture, conceptual and functional properties and their relation affecting each other (Vojislav et al, 2013; Kimbel, 2011; 2012; Yaneva, 2009; Stankovic et al. 2006; Abbot, 2001). Children's ability to attend a place knowledgeably and their attempt to experience a place fully, empathetically, and sympathetically depends on having familiar feelings about their environment (Hosny et al.,2013; Abbas \& Othman, 2010; Han et al., 2008; Read, 2007; Dudek, 2005; 2000) Meanings of a space are not always shared universally or objectively, it is subjective and "lived" in nature. Children construct sense of space with complex, layered affordances and meaning (Lim, Barton, 2010). The kind of knowledge, skills and affective meanings which the children develop, uniquely constructed by lived experiences and layered with significances and meanings determined by culture (Lim, Barton, 2010). Including such characteristics are determined pedagogically, geographically, socially, culturally etc..in the physical environment. So, culture oriented design model to examine the following relations and structure the theoretical framework of the study. So this part of the study tries to convey fallowing items as such;

- Indirect and direct relations between cultural-physical sub-components creating spatial set-up,

- Culture, location, education model, child-environment and child-parent-trainer relations directing the design, as well as variables rising due to legal arrangements,

- Relation of cultural items with space groups in the sense of education, maintenance and requirements of the child, their usage principles, interior space features and furniture-equipment.

\section{Preschool Interior Design Model}

The framework of preschool and kindergarten interior design set up should cover above stated features

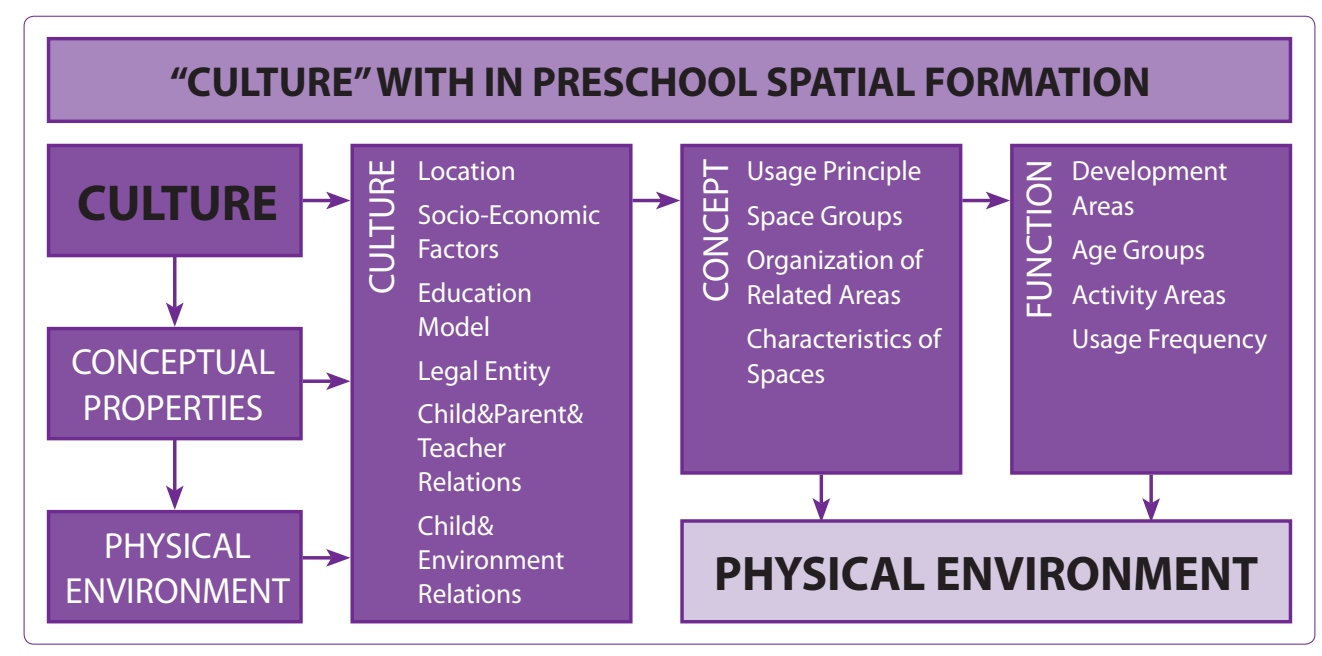

Figure 2. Physical environment of preschool interior set-up within the scope of cultural entities. 
are complex and variable with respect to social values (Wylie\&Thompson, 2003; Smith et al, 2000; Lamp,1998; Banett, 1997). According to Gürkaynak (1988), when physical environment is considered as a system consisting of many sub-factors, each level of the system has physical characteristics affecting the behaviour and each level constitutes the part of the system together with other levels. Therefore, according to the study, in order to achieve Ideal Pre-school Interior Design Set-up, characteristics acknowledged at universal platform and related with child development and requirements should be considered with culture, location, education system, child-environment relation (psycho-social indicators), child-parenttrainer relations and legal arrangements. These relationships and factors are examined and viably explored in detailed in the following section of study. Especially in the period of early childhood when a large portion of a child's life is spent in the interior environment, it is clear that the quality of this living in the interior environment as part is crucial in children's development.

On the other hand children are not usually involved in planning the buildings they have to live in. They are, in fact, invisible clients. They spent their lives in a built environment, yet they have no input into the design, aesthetic, function or organization of it (Dudek, 2005; Maxwell, 2003; Moore, 2002; Korpela et al., 2002). It is therefore up to the adults in charge to develop suitable design criteria. In this context one of the most important issues in child-parent or/and teacher relationship is the awareness of the important contributions of the physical environment to the development of the children (Han et al., 2008; Rudge\&Driskoll, 2005; Burdurlu et al., 2004; Moore, 2002; Dogramaci, 1994). Because, the affinity of a children's spaces are reflected in the interior environment within the scope of parents/teacher knowledge. The attitude, knowledge and expectations of the them affect the designing process of any spatial unit designed for children. Adult description of the ideal context environment can provide designers with significant insight to design priorities of the physical environment of early childhood spaces which change from culture to culture (Kimbel, 2012; 2011; Yalcin, 2011; Han et al., 2008; Burdurlu et al., 2004; Dudek, 2001). Cultural items determined and presented by the adults consideration about the spatial design Since the space not only needs to represent the developmental stage but also it has to be taken as a whole with many factors like a child's psychology, development, identity, abilities and culture which are shaped and developed by the adults.(Stankovic\&Stojic, 2007; Christensen \& James, 2000; Tolfree\&Woodhead, 1999; Miller, 1986). So, the quantitative method of this study is applied to the parents, teacher and administrative staff of the preschools in the latter part.
To sum up children develop affective relationships in various contexts with their environment deeply and in layered functionalities. These relationships provide not only emotional and psychological affordances, but also cognitive and social affordances which satisfy sense of place, integrate and enable engagement of children (Lim, Barton, 2010; Clark, 2005; Day, 2002; 1990; Gustafson, 2001). As mentioned before configuring environmental design criteria's for them covers many aspects such as parents, values, beliefs, social environment, physical setting, aesthetic, education etc. which are culturally oriented (Bell, 2006; 2002; Clark, 2005; Derr, 2002; Rapoport, 2000). These contextual connections and relations with the physical environment shaped the body of the study and design model set-up of preschool interiors in Ankara. In this framework, items identified as "specific to the culture" within the design setup of preschool interior spaces and findings obtained as a result of theoretical analysis of conceptual components affecting physical space are analysed over the selected preschools in Ankara chosen as sample site in accordance with different categorising a cultural typology in the scope of the study area. These preschool education centres are those applying a specific education model (Montessori, Head Start etc.) education model, providing education in English, highlighting features like Physical Space Comfort, etc. and those created their corporate identity thanks to above counted features. So, the study conveyed its quantitative environment as such;

\section{Environmental Setting}

15 pre-school education centres and 200 parent, trainer, manager were analysed; In these centres it is observed physical features support formation of their corporate identity and many socio-economic factors in sharpening the physical characteristics of these centres. Above stated parameters act as determiners in creation of design criteria with respect to location and conditions of each entity. Conceptual components affecting physical space of preschool education centres analysed are education model, socio-economic conditions, and appreciation of adults, child-teacher-parent relations, culture and location. This classification has driven the study to eliminate data for comparison between dynamics and approval for the stated grounded theory in a micro scale in such a way that most of the studies about design and culture consist of comparisons of two or more culture in a specific function, space etc. This study covers and emphasises even if above mentioned subcomponents of culture effects Interior Spatial set-up. For this reason four typologies have been identified and the preschool centers are selected according these classification. So, these 15 pre-school centres were selected and classified on account of their cultural variables which consist four cultural typologies as following; 
Type 1; Those applying specific (Like Montessori, Head Start etc...) education model; These preschools are commonly preferred in which unique spatial required specified and obligated according to the education model.

Type 2; Those providing education in English; Preschools medium of education are English, all system and spatial arrangements are allocated around this purpose.

Type 3; Branches of a "Franchise"; Chain of institutionalized and well-known Preschool centre these preschool type is regulated to provide specific spatial quality and objectives which also reflect their institutional identity.

Type 4; Those of showy/attractive spatial entities; These entities are commonly preferred because of their comfort, many attractive facilities (swimming pool, cinema, play areas etc..) covered and provided in the a showy/attractive structure.

\section{Development of Hypotheses}

The problems and hypotheses determined in the preschool Interior Space are as follows:

\section{Problem Sentence}

Pre-school interior spaces where the children spend most of their time out of their homes should overlap with educational activities and be designed in accordance with culture, psychology, improvement, identity, knowledge and skills of the children and should have its spatial statement as a whole and manifest itself. However, cultural dimensions of within this spatial formation is mostly overlooked. (Read, 2007; Kounin, Sherman, 2001; Moore, 1995; Gump, 1987).

\section{Sub-problems}

"Culture" within a preschool interior design setup is a phenomenon including a very wide and abstract range of concepts. Clearing these concepts up shall assists clearing how the parts of the culture interrelate as well as its components and propositions.

However the basis of this understanding explains childculture-space interaction in pre-school interior design where the Environmental Psychology, Education and Design sciences.

Within the scope of design set-up, "culture" should be in accordance with the physical components of the environment and should support them.

Although education is structured over universal concept, impacts of cultural differences within the community on education are inevitable. So, the space designed should be suitable in order to realize targets and objectives of education, increase the materialization of its content, implementation of education curriculum and healthy application of the evaluation.

\section{Hypotheses}

H1: Not much significant difference around the measured items will be between the cultural typologies.

$\mathrm{H} 2$ : Space -Education relationship is taken in consideration and is one the major criteria for preference.

H3: Interior Spatial Quality has been criticized in terms of children development while preference.

H4: Facilities are provided differs between typologies and their interior spatial objectives (spatial arrangements, atmosphere, furniture etc...) accordingly

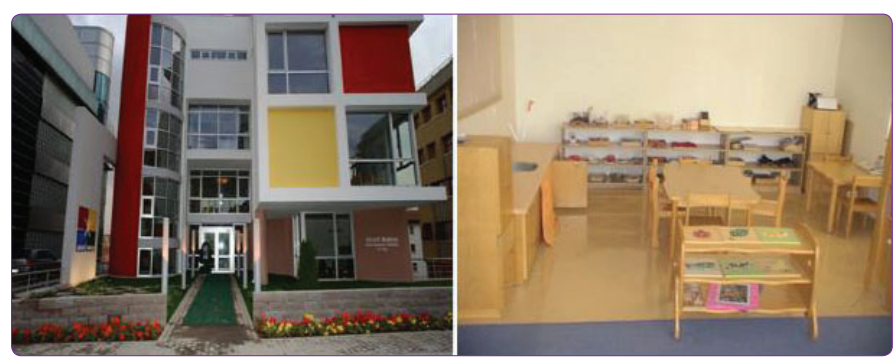

Figure 3. Sample of Preschool which applying Montessori Education Model.

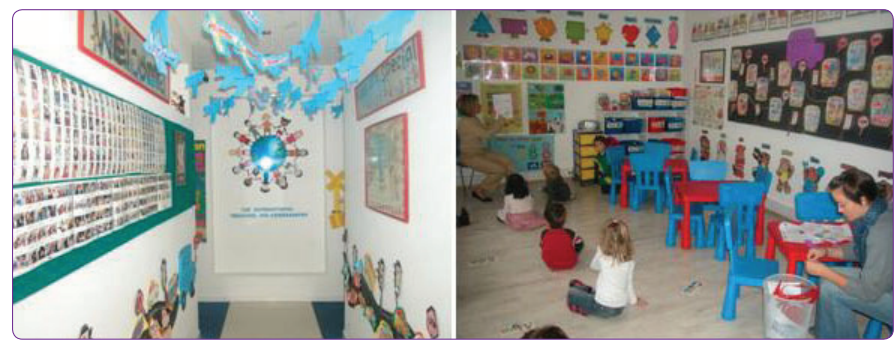

Figure 4. Sample of Preschool which providing education in English Language.
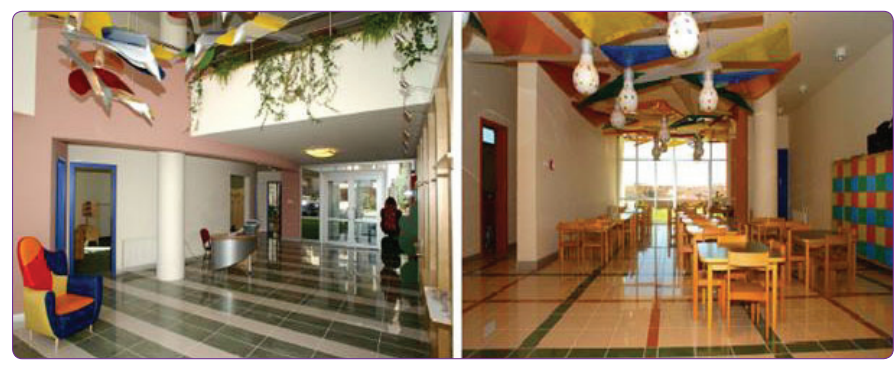

Figure 5. Sample of Preschool which is a branch of Franchised Chain.

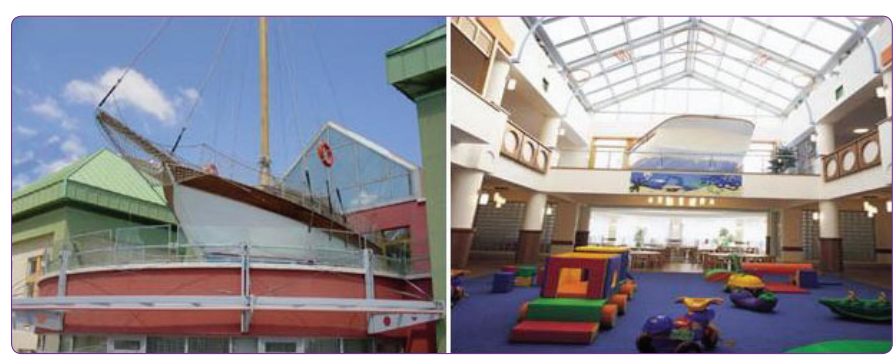

Figure 6. Sample of Preschool which has attractive with its spatial objectives. 
Table 1. Selection of the subjects

\begin{tabular}{lcc}
\hline & n & Mean $^{\text {a }}($ SD) \\
\hline Age & 200 & $35,20(4,90)$ \\
Education & 192 & $2,80(0,90)$ \\
Gender & 183 & $2,90(0,80)$ \\
\hline
\end{tabular}

SD: Standard deviation.

$\mathrm{H} 5$ : Socio-economical indirect parameter is one of major identifier of the interior spatial quality

H6: There are direct and indirect relations between typologies of cultural parameters and Interior Spatial Formation.

\section{Methodology}

The following methods were employed to test the hypotheses.

This research was carried out at 200 respondents of 15 pre-school establishments located in Çankaya and Çayyolu regions. The respondents consist of parents, teacher and other school personals. In the table above (ratio(scale) measuring level of respondents degree with ordinal measuring level with are given as such degree Level (high school=1, associate degree $=2$, undergraduate $=3$, graduate $=4$ ). In the table N: declaration, M: Mean, SD: Standard Deviation are presented. Average of the respondents age is 35,2 , their degree level is 2,9 and gender distribution is 2,8 . So, data's show that respondents consist of high degree, young and mostly female. The questionnaire was filled out various time during the weekdays. The subjects completed their questionnaires in approximately 15 minutes. The data on the questionnaires were obtained through face-to-face interviews in the preschool education centres during a period of fifteen days at the beginning of 2014.

\section{Design Questionnaire}

The questionnaire consisted of four parts: The first part was composed of questions aimed at determining general information for the age, gender and degree of the subjects.

The second part consisted of a seven-point Likert-type scale for the sub-components (Location, Education Model, Socio-Economical etc... depended variables) evaluation of depended cultural variables. to determine four typologies attribute a seven-point Likert-type scala is used. In this scala bigger numbers presents more positive responses.

The third part examines the attributes of interior space and furniture (needs and requirements) with a seven point Likert-type scala. In this scala bigger numbers presents more positive responses.

Last partinquire in to respondents the (four typologies) attribute of interior space and their relations to the cultural variables by using a four Linkert-type scala. In this scala bigger numbers presents more positive responses.

\section{Evaluation of the Data}

The study is carried with 200 including 100 parents and 100 staffs. Completing 22 Data transfer programs Data's were analysed by using IBM SPSS Statistics. Data's were analysed by categorical variables for frequency distribution (F, \%) (Table 4), for continues variables the identifier (M, SD) (Table 1, Table 6, Table 8) are used. Kolmogorov Smirnov are used for continues variables normality test has been applied. Data's have shown that for assumption variables providing normality parametrical tests, for nor-

Table 2. Relations of fact of preferences and cultural variables

\begin{tabular}{|c|c|c|c|}
\hline \multirow[t]{3}{*}{ Cultural variables } & \multicolumn{3}{|c|}{ Facts of preferences } \\
\hline & Parents & Staff & \\
\hline & Mean $^{a}$ (SD) & Mean (SD) & t-value ${ }^{b}$ \\
\hline Education & $3.85(2.08)$ & $4.03(1.73)$ & -0.667 \\
\hline Developmental features & $4.55(2.11)$ & $5.34(7.47)$ & -1.018 \\
\hline Child-env. relations & $4.15(2.02)$ & $4.34(1.71)$ & -0.718 \\
\hline Location & $3.18(1.92)$ & $3.67(1.92)$ & $-1.805^{*}$ \\
\hline Parent-child-institution relations & $3.84(1.94)$ & $3.98(1.80)$ & -0.529 \\
\hline Legal arrangements & $4.59(2.08)$ & $4.64(1.63)$ & -0.189 \\
\hline Socio-economic facts & 4.33 (1.99) & $4.79(1.72)$ & $-1.749^{*}$ \\
\hline Institutional Identity & $4.46(2.11)$ & $4.70(1.82)$ & -0.861 \\
\hline Visual attractiveness (showiness) & $3.91(2.17)$ & $4.04(1.99)$ & -0.442 \\
\hline Other & 4.84 (1.99) & $4.93(1.75)$ & -0.340 \\
\hline Physical relations & $5.02(2,00)$ & $5.09(1.89)$ & -0.254 \\
\hline
\end{tabular}

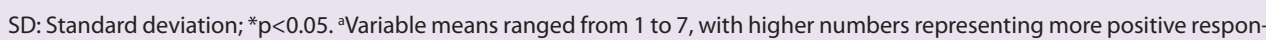
ses. ${ }^{b} t$-values: It is the result of comparison of parents and staff variables. 


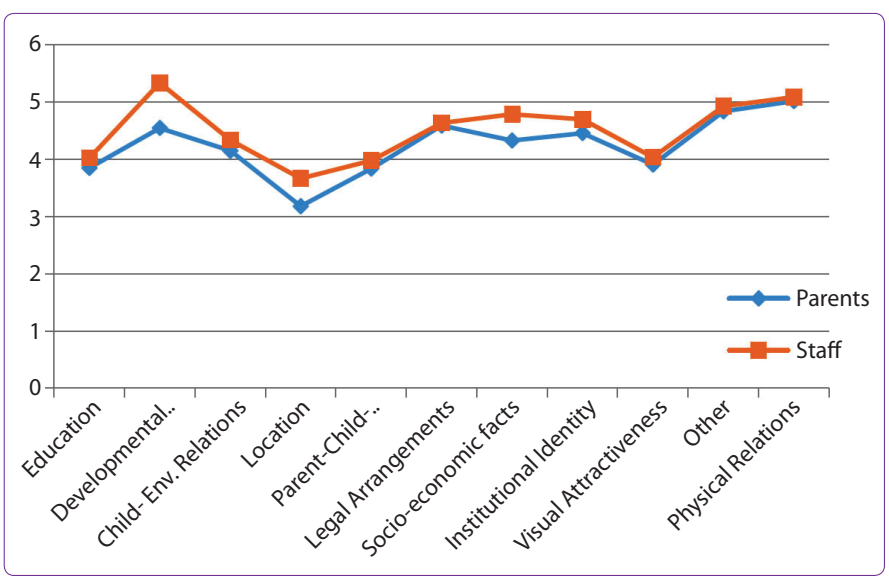

Figure 7. Comparisons of preference between parents and staff. Note: Means of the variables listed between 1-7 (large numbers are negative responses).

mality assumption not providing nonparametric tests are used. Two independed groups two independed samples were analysed with t test (Table 2) to see weather two two independed groups are different or not. Chisquare test (Table 3, Table 5) is used to see if two categorical variables are in relation with each other. Kruskal-Wallis test is used to see difference between more than one groups. Moreover graphics are provided results to show groups (preschool type, respondents) average values.

\section{Results}

The statistical relationships among number of parents and staff of expectations and requirements the preschool education centers and their priorities were analyzed. The results of the questionnaire have been given in Table 2 as the means, standard deviations and t-values for each of the dependent variable items. According to the results parents and staffs, all of the items were facts which determines their priority and are in significant values. Only significant difference of $t$ value of the respondents resulted in Socio-Economical and Locational Factors. Data's show that these depended variable are both parents and teacher (other staffs) taken in consideration with significant values. Above mentioned items are in terms of T scale coherent between Respondents (parent and staff).

Respondents are categorized and analyzed according to their approach to the Interior Spatial quality in terms of children development. Respondents are categorized to parents and staffs (teacher, manager, owner etc.); Preschools to Typologies which is defined as Important and Not Important. Of a total of $\% 87$ parent found the Interior

Table 3. Attribute and relationship spatial quality in terms of children developments and preschool centers

\begin{tabular}{|c|c|c|c|c|c|c|c|}
\hline \multirow{2}{*}{\multicolumn{2}{|c|}{$\begin{array}{l}\text { Spatial quality in terms of } \\
\text { children and development }\end{array}$}} & \multicolumn{2}{|c|}{ Important } & \multicolumn{2}{|c|}{ Not Important } & \multicolumn{2}{|c|}{ Total } \\
\hline & & \multirow{2}{*}{$\begin{array}{c}\mathbf{F} \\
87\end{array}$} & \multirow{2}{*}{$\begin{array}{c}\% \\
87.0\end{array}$} & \multirow{2}{*}{$\begin{array}{l}\mathbf{F} \\
13\end{array}$} & \multirow{2}{*}{$\begin{array}{c}\% \\
13.0\end{array}$} & \multirow{2}{*}{$\begin{array}{c}\mathbf{F} \\
100\end{array}$} & \multirow{2}{*}{\begin{tabular}{|l|}
$\%$ \\
50
\end{tabular}} \\
\hline Respondents & Parents & & & & & & \\
\hline & Staffs & 92 & 92.0 & 08 & 08.0 & 100 & 50 \\
\hline \multirow[t]{4}{*}{ Preschool centers } & Type 1 & 51 & 81.6 & 12 & 18.4 & 63 & 31.0 \\
\hline & Type 2 & 37 & 60.7 & 24 & 39.3 & 61 & 30.5 \\
\hline & Type 3 & 27 & 66.6 & 09 & 33.4 & 36 & 18.0 \\
\hline & Type 4 & 24 & 76.4 & 09 & 24.6 & 43 & 21.5 \\
\hline Total & & 139 & 74.5 & 61 & 26.5 & 200 & 100 \\
\hline
\end{tabular}

Respondents Status: $x^{2}: 9.874, d f: 1, p=0.002$, Preschool Centers: $x^{2}: 4.346 \mathrm{df}: 3, p=0.226$.

Table 4. Respondents evaluation of preschool spatial requirements

\begin{tabular}{|c|c|c|c|c|c|c|c|}
\hline \multicolumn{2}{|c|}{ Spatial requirements } & \multicolumn{2}{|c|}{ Adequate } & \multicolumn{2}{|c|}{ Inadequate } & \multicolumn{2}{|c|}{ Total } \\
\hline & & $\mathbf{F}$ & $\%$ & $\mathbf{F}$ & $\%$ & $\mathbf{F}$ & $\%$ \\
\hline \multirow[t]{2}{*}{ Respondents status } & Parents & 47 & 47.0 & 53 & 53.0 & 100 & 50 \\
\hline & Staff & 40 & 40.0 & 60 & 60.0 & 100 & 50 \\
\hline \multirow[t]{4}{*}{ Preschool Centers } & Type 1 & 25 & 41.7 & 35 & 58.3 & 60 & 30.0 \\
\hline & Type 2 & 26 & 42.6 & 35 & 57.4 & 61 & 30.5 \\
\hline & Type 3 & 17 & 47.2 & 19 & 52.8 & 36 & 18.0 \\
\hline & Type 4 & 19 & 44.2 & 24 & 55.8 & 43 & 21.5 \\
\hline Total & & 87 & 43.5 & 113 & 56.5 & 200 & 100 \\
\hline
\end{tabular}

Respondents Status: $x^{2}: 0.997$, df: 1, $p=0,392$, Preschool Centers: $x^{2}: 0.312, d f: 3, p=0,958$. 
Spatial Quality Important, 13\% Not Important. Out of the total 92\% Stafffind the Interior Spatial Quality important, $8 \%$ Not Important. The attributes to the Spatial Quality between the Preschool are as such; $(81,6 \%)$ of type1 Respondents Indicated as Important, 18,4\% Not Important; 60,7\% of type 2 found it Important; 39,3\% Not Important; $66,6 \%$ of type3 found it Important, 33.4\% Not Important; 76,4\% found it Important type4, 26,4\%'inin Not Important. In the chi square test carried out there was no significant difference between typologies of preschools $(p=0,226>0,05)$; parents and staffs $(p=0,002<0,05)$.

According to Table 5 it can be seen $47 \%$ of parents found spatial quality adequate in terms of children development, $53 \%$ found in adequate. Out of $40 \%$ of Staff respondents found spatial quality adequate while $60 \%$ of staff did not. On the other hand the difference between Preschool typologies as following; $41,7 \%$ of type 1 found it adequate $58,3 \%$ did not; $42,6 \%$ of type 2 responded as adequate $57,4 \%$ did not; $47 \%, 2$ of type 3 responded positively while $52,8 \%$ did not; $44 \%$, 2 of type 4 determined as adequate, while $55,8 \%$ 'i did not. There is no significant relations between Parents and Staff. ( $p=0,392>0,05)$ and Typologies $(p=0,958>0,05)$ Spatial Adequacy have been found $(H 3)$.

According to Table 4. Results of respondents to the spatial characteristics which are taken to consideration in the formation and selection of preschools the following percentages; Within the General Characteristics took account of Quality (76,9\%), Aesthetics $(58,1 \%)$, Not containing harmful substances $(47,5 \%)$, Functionality $(63,8 \%)$, Durability $(28,8 \%)$, Safety / security $(61,9 \%)$, Guarantee Period $(35 \%)$ and Others $(11,3 \%)$.To the Specific Characteristics; Education (25\%), Legal Arrangement (2,5\%),Development Qualifications (20\%), Parent Expectations (22,5\%), Adaptability to different act $(1,3 \%)$, Socio-Economic and $(41,3 \%)$ Location (1,3\%).

Each question related to each scale has four levels (not important $=1$, slightly important $=2$, important $=3$, very important=4). Scales regarding interior design, atmospheric properties and furniture-equipment features have five sub-questions each and the scale concerning the general standards of the institution is completed sub-questions. The questions are shortly as given in the chart above.

The average significance level regarding space flamboyancy in the interior design properties scale is 2.2 for the first typology and 1.9 for the first meaning the school studied within the first typology considers space flamboyancy to be more important and while the average importance level of the question related to saliency of the furniturefittings properties is 2.9 for the second typology it is 3.2 for the fourth typology explaining us that the fourth typology gives more importance for the furniture and equipment to grab attention than the second typology on average.

In the chart above the four schools are studied respectively within the scope of four scales whether they have differences or not is examined. The significance level is determined according to the total of the answers given by each subject to the questions for each scale. A subject may get at the least 5 (for the scale of general standards of the preschool institution at least 7) at the most 20 (for the scale of general standards of the preschool institution at most 28) points of valuation over the scales where not important option equals 1 point and very important option equals 4 . The higher a rate is given more importance is attributed to the scale. The method used in this analysis is one way ANOVA. Nevertheless, since the "homogeneity of variances" presumption which is among the presumptions necessary for one way ANOVA analysis cannot be obtained, Kruskal Wallis method as the non-parametric alternative of this method has been used while contrasting the scale related to interior design properties.

The null hypothesis to be tested via these methods are a; HO: Regarding the scales in question there is no difference among typologies in terms of significance level. The alternative hypothesis on the other hand is HA: At least one typology is different from the others on the basis of significance level. Here inference level is taken as 0,05 . As a result of the analysis done for the first scale $p=0,000$ (Chi square $=26,548$ ) is obtained. Thus, the null hypothesis

Table 5. Responses to spatial characteristics

\begin{tabular}{|c|c|c|c|c|c|}
\hline General characteristics & $\mathbf{F}$ & $\%$ & Specific characteristics & $\mathbf{F}$ & $\%$ \\
\hline Quality & 123 & 76.9 & Education & 40 & 25 \\
\hline Aesthetics & 93 & 58.1 & Legal arrangement & 4 & 2.5 \\
\hline Not containing harmful substances & 76 & 47.5 & Development & 32 & 20 \\
\hline Functionality & 102 & 63.8 & Parent expectations & 36 & 22.5 \\
\hline Durability & 46 & 28.8 & Adaptability to different & 2 & 1.3 \\
\hline Safety / security & 99 & 61.9 & Socio-economic & 66 & 41.3 \\
\hline Guarantee period & 56 & 35 & Location & 2 & 1.3 \\
\hline Others & 18 & 11.3 & - & - & - \\
\hline
\end{tabular}


Table 6. Attribute of interior spatial quality between typologies of preschools

\begin{tabular}{|c|c|c|c|c|}
\hline & Type 1 & Type 2 & Type 3 & Type 4 \\
\hline & Mean $^{a}$ (SD) & Mean $^{a}$ (SD) & Mean $^{\mathrm{a}}$ (SD) & Mean $^{\mathrm{a}}$ (SD) \\
\hline \multicolumn{5}{|l|}{ Interior properties } \\
\hline Visual attractiveness & $2,2(0,8)$ & $2,5(0,8)$ & $1,9(0,7)$ & $3(0,6)$ \\
\hline Support of developmental areas & $3,9(0,3)$ & $3,8(0,4)$ & $3,8(0,4)$ & $3,7(0,4)$ \\
\hline Physical comfort & $3,7(0,6)$ & $3,7(0,5)$ & $3,4(0,6)$ & $3,5(0,5)$ \\
\hline Support of creativity & $3,4(0,8)$ & $3,9(0,4)$ & $3,1(0,8)$ & $4(0)$ \\
\hline Purity and natural & $3,2(0,7)$ & $3,3(0,8)$ & $3,2(0,6)$ & $3,4(0,6)$ \\
\hline \multicolumn{5}{|l|}{ Spatial qualification } \\
\hline Amount of area per child & $3,6(0,5)$ & $3,3(0,5)$ & $3,6(0,4)$ & $3,5(0,5)$ \\
\hline Different activity areas & $3,7(0,5)$ & $3,6(0,5)$ & $3,8(0,4)$ & $3,2(0,6)$ \\
\hline Aesthetic pleasing space & $3(0,9)$ & $2,7(0,7)$ & $3(0,7)$ & $3,1(0,4)$ \\
\hline Material quality & $3,6(0,6)$ & $3,3(0,5)$ & $3,5(0,5)$ & $3,6(0,5)$ \\
\hline Flexibility and multi-functionality & $3,7(0,4)$ & $3,6(0,5)$ & $3,6(0,4)$ & $3,4(0,5)$ \\
\hline Bright and sunny spaces & $3,7(0,5)$ & $3,6(0,6)$ & $3,8(0,4)$ & $3,7(0,4)$ \\
\hline \multicolumn{5}{|l|}{ Atmospheric properties } \\
\hline Figured and remarkable & $2,7(0,9)$ & $2,9(0,7)$ & $2,7(0,8)$ & $3,3(0,6)$ \\
\hline Natural colors & $3(0,6)$ & $2,8(0,9)$ & $3(0,7)$ & $2,8(0,7)$ \\
\hline Natural lighting & $3,6(0,6)$ & $3,9(0,3)$ & $3,7(0,5)$ & $3,7(0,4)$ \\
\hline Natural materials & $3,7(0,5)$ & $3,5(0,6)$ & $3,7(0,5)$ & $3,5(0,5)$ \\
\hline Natural and instructive texture & $3,4(0,6)$ & $3,2(0,7)$ & $3,6(0,5)$ & $3,3(0,4)$ \\
\hline \multicolumn{5}{|l|}{ Furniture } \\
\hline Natural material & $3,7(0,5)$ & $3,6(0,5)$ & $3,8(0,4)$ & $3,5(0,5)$ \\
\hline Proportion, ergonomic & $3,6(0,5)$ & $3,8(0,5)$ & $3,7(0,5)$ & $3,4(0,5)$ \\
\hline Remarkable & $3(0,9)$ & $2,9(0,8)$ & $2,9(0,8)$ & $3,2(0,4)$ \\
\hline Mobility, flexibility & $3,4(0,6)$ & $3,2(0,8)$ & $3,3(0,7)$ & $3,2(0,6)$ \\
\hline Multi functionality & $3,6(0,6)$ & $3,1(0,8)$ & $3,5(0,6)$ & $3,4(0,6)$ \\
\hline
\end{tabular}

Table 7. Comparison of preschool entities typologies and spatial evaluations

\begin{tabular}{|c|c|c|c|c|c|c|c|c|c|c|c|c|}
\hline & \multicolumn{3}{|c|}{ Interior properties } & \multicolumn{3}{|c|}{ Spatial qualification } & \multicolumn{3}{|c|}{ Atmospheric properties } & \multicolumn{3}{|c|}{ Furniture } \\
\hline & $\mathbf{n}$ & Mean $^{\mathrm{a}}$ (SD) & $\mathbf{p}$ & $\mathbf{n}$ & Mean $^{\mathrm{a}}$ (SD) & $\mathbf{p}$ & $\mathbf{n}$ & Mean $^{\mathrm{a}}$ (SD) & $\mathbf{p}$ & $\mathbf{n}$ & Mean $^{a}$ (SD) & $\mathbf{p}$ \\
\hline Type 1 & 64 & $15,9(2,3)$ & 0,000 & 60 & $25,1(2,4)$ & 0,146 & 57 & $16,4(2)$ & 0,984 & 60 & $17,3(2)$ & 0,403 \\
\hline Type 2 & 36 & $17(1,4)$ & & 34 & $24(2,5)$ & & 31 & $16,6(2)$ & & 34 & $16,6(2,3)$ & \\
\hline Type 3 & 45 & $14,6(3)$ & & 34 & $25(2,3)$ & & 38 & $16,6(2,3)$ & & 36 & $17,3(2,1)$ & \\
\hline Type 4 & 32 & $17,7(1,4)$ & & 39 & $24,3(2,1)$ & & 39 & $16,4(1,6)$ & & 39 & $17(1,3)$ & \\
\hline
\end{tabular}

as "There is no difference in terms of significance level among typologies on the basis of interior design properties" is disaffirmed $(p<0.05)$. So we are able to say that at least one typology attributes importance to interior design unlike the others. In order to find the answer for the question that what difference between which two typologies resulted in the disparity in question the Dunnett T3 and Games-Howell tests are done. Consequently, substantive diversities are detected between the first and the second and fourth; between the second and the third and between the third and the fourth typologies.
As a result of the analysis done for the second typology $p=0,146(F=1,820)$ is obtained. Thus, the null hypothesis as "There is no difference among the typologies in terms of significance level on the basis of "Spatial Qualification" could not be disaffirmed ( $p>0.05$ ) showing all the typologies attribute equal importance to the general standards of the preschool institution statistically.

The analysis for the third scale resulted as $p=0,984$ $(F=0,052)$ thus the null hypothesis as "There is no difference among typologies in terms of significance level on 
Table 8. Attribute of respondents to cultural in relation to interior spatial qualification

\begin{tabular}{|c|c|c|c|c|}
\hline & Type 1 & Type 2 & Type 3 & Type 4 \\
\hline & Mean $^{a}$ (SD) & Mean $^{\mathrm{a}}(\mathrm{SD})$ & Mean $^{\mathrm{a}}$ (SD) & Mean $^{\mathrm{a}}$ (SD) \\
\hline Coincide with Educational facilities & $4,13(1,89)$ & $3,85(1,78)$ & $3,66(1,8)$ & $4,02(2,19)$ \\
\hline Flexibility for Diff. Educational facilities & $4,91(1,92)$ & $5,91(9,45)$ & $3,86(1,72)$ & $4,51(2,18)$ \\
\hline Adaptability to multi functional areas & $4,53(1,82)$ & $4,14(1,82)$ & $3,77(1,88)$ & $4,37(1,96)$ \\
\hline Convenient to children development & $3,10(1,94)$ & $3,47(1,90)$ & $3,38(1,84)$ & $3,83(2,03)$ \\
\hline Coincide with parent expectation & $3,66(1,94)$ & $4,08(1,88)$ & $3,77(1,77)$ & $4,11(1,84)$ \\
\hline Coincide with manager/teacher expectation & $4,83(1,90)$ & $4,72(1,74)$ & $3,94(1,63)$ & $4,72(2,10)$ \\
\hline Meet legal requirements & $4,51(1,87)$ & $4,60(1,90)$ & $4,19(1,75)$ & $4,86(1,92)$ \\
\hline Attractiveness, Visual Impression & $4,80(1,92)$ & $4,78(1,91)$ & $4,25(1,93)$ & $4,25(2,13)$ \\
\hline Institutional Requirement & $4,30(2,05)$ & $3,98(1,99)$ & $3,88(1,96)$ & $3,58(2,33)$ \\
\hline Location/Physical Requirement & $5,06(1,90)$ & $4,85(1,73)$ & $4,63(1,92)$ & $4,88(2,01)$ \\
\hline Socio-economic requirements & $5,30(1,86)$ & $5,14(1,88)$ & $4,77(1,98)$ & $4,81(2,10)$ \\
\hline
\end{tabular}

the basis of atmospheric properties" could not be disaffirmed ( $p>0.05)$. All the typologies attribute significance equally to the atmospheric properties statistically.

The analysis for the fourth scale resulted as $p=0,403$ $(F=0,984)$. Thus the null hypothesis as "There is no difference among typologies in terms of significance level on the basis of atmospheric properties" could not be disaffirmed $(p>0.05)$. All the typologies attribute significance equally to the atmospheric properties statistically.

This part of statistical analysis tries to see preschools interior spatial attributes in relation to the cultural components consistency of above evaluations; It was observed that there are significant items of relations between them. No significant difference on the average requirements of relations of the subjects and Standard Deviations was found between type of Preschools. Almost all values of the items are above average and there is no significant difference between typologies. So, It can be seen that within the formation of Interior Space Educational facilities, Flexibility, Adaptability, children development, Parents' Expectations Manager/Teacher Expectation, Legal Requirements, Attractiveness, Institutional Requirement, Location/Physical Requirement, Socio-economic Requirements have been taken in to consideration and the Mean Values are intimate between the typologies as it is shown in Figure 8 .

\section{Results}

Parents are now much more investigative and aware of the importance of pre-schooling thanks to the increasing opportunities (Vojislav et al., 2013; Abbas \& Othman, 2010; Derr, 2002; Moore, 1987). The effort to provide better conditions brought by the competition can be seen in various ways in the preschool interiors. However "qualified" in terms of physical environmental qualities, is a concept considerably relative and difficult overlapping phenom- enon in children spaces (Read, 2007; Derr, 2002; Dudek, 2001; Gür \&Zorlu, 2002; Bozdayı, 1988). Pre-school centres have increased rapidly and all of them try to sustain their existence by means of activities supporting child development and opportunities (Kostić et al. 2014; Abbas et al. 2013). Attitude, knowledge and expectations of above stated individuals affect design process of any pre-school entity. Parents and educators' description of the ideal learning environment provides designers with significant insight into design priorities for the physical environment of early childhood centres (Read, 2007; Bell, 2002). Descriptions about the key spatial qualities are emphasized. Since children spaces not only needs to represent the developmental stage but also it has to be taken as a whole with many factors like a child's psychology, development, identity, abilities and culture of children because children develop affective relationships in various contexts with their environment deeply and in layered functionalities

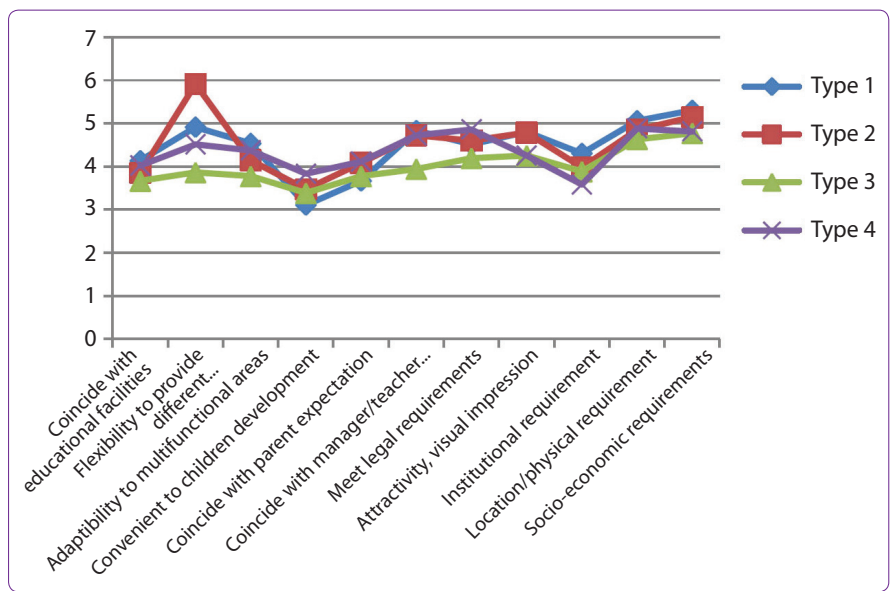

Figure 8. Responses means to variable items of type 1, type 2, type 3 and type 4 preschools. Note: Means of the variables listed between 1-7 (large numbers are positive responses). 
(Dudek, 2005; 2000; Kyle,et al., 2004; Rapoport, 2000; Hay, 1998). These relationships provide not only emotional and psychological affordances, but also cognitive and social affordances which satisfy sense of place, integrate and enable engagement of children which also require proposition with regard to universally accepted values for children development and its subcomponents of comprehension will be the scope of spatial design set-up (Lim \& Barton, 2010; Spencer \& Blade, 2006; Old, 2001; Hay, 1998).

Correspondingly, the study tries to focus and emphasize relationship of culture-preschool interior spatial set-up and applied a questionnaire to the parents, teachers, manager and other administrative staffs to recognize their attitude as representative subcomponents; Educational facilities, Flexibility, Adaptability, children development, Parents' Expectations Manager/Teacher Expectation, Legal Requirements, Attractiveness, Institutional Requirement, Location/ Physical Requirement, Socio-economic Requirements, Furniture-Fittings Properties. To catch these categorizations the study selected the preschool entities and a classification (according to a specific education model, English education, Franchising, Comfort) with common characteristics to measure the affects of above mentioned items on respondents and their reflection to preschool interior.

\section{Conclusion and Discussion}

Most of the cultural studies examines its argument on comparing two or more different culture, what's unique in this study is; it shad the light not only a smaller scale of an area but also categorizes the study entities to get more specific and detailed evaluations. In this respect The questionnaire consisted of four parts: The first part was composed of questions aimed at determining general information for the age, gender and degree of the respondents whom average age were 35,5 (young), degree 2,9 (high level around undergraduate), gender 2,8 (mostly women).

The second part consisted of a seven-point Likert-type scale for the sub-components of culture (Location, Education Model, Socio-Economical etc... depended variables) evaluation of depended cultural variables (H5). to determine four typologies attribute a seven-point Likert-type scala show that these items are determiners of preschool preference (Table 2). $75 \%$ of respondents are aware the importance of spaceeducation relations (Table 3 ) on children development, but more than half $56.5 \%$ of the respondents find spatial requirements inadequate of the preschool (H3).

The third part (Table 5 and 6 ) examines the attributes of interior space (needs and requirements) Likerttype scala. Within the General Characteristic spatial quality took account of Quality (76,9\%), Aesthetics (58,1\%), Not containing harmful substances $(47,5 \%)$, Functionality $(63,8 \%)$, Du- rability (28,8\%), Safety / security (61,9\%), Guarantee Period (35\%) and Others (11,3\%). To the Specific Characteristics; Education (25\%), Legal Arrangement (2,5\%),Development Qualifications (20\%), Parent Expectations (22,5\%), Adaptability to different act (1,3\%), Socio-Economic and (41,3\%) Location $(1,3 \%)$. Besides completing upon the evaluation of the preschool centers adopting the four different typologies, within the context of four separate scales, These four typologies consist of separate scales to be referred to in the evaluation depend on the questions asked about the interior design features, spatial qualification, atmospheric properties and furniture and fittings with subheadings. These dimensions resulted as coherent values between typologies except type 2 .

Last part measures relationship Interior Spatial set-up with Educational facilities, Flexibility, Adaptability, children development, Parents' Expectations Manager/Teacher Expectation, Legal Requirements, Attractiveness, Institutional Requirement, Location/Physical Requirement, Socioeconomic Requirements. This part (Table 7 and Figure 2) inquire in to respondents the (four typologies) attribute of interior space and their relations to the cultural variables by using a four Linkert-type scala which was Almost all values of the items are above average value and there are no significant difference resulted between typologies $(\mathrm{H} 6)$.

Thus although the study has developed in four different typologies, the scales, measurement and values resulted very close between typologies $(\mathrm{H} 1)$. The reason for this congruency is the socio economic, location parameter directly since the preschools have selected from same region of Ankara and parentteacher-child, child-environment or even legal regulations are relations indirectly. Many factors have been examined in the framework of this study which provide design criteria and critical point view for the designer and education community.

\section{References}

Abbas, M. Y. \& Othman, M. (2010)“Social Behaviour of Preschool children in relation to physical spatial definition" Volume 5, 2010, pp. 935-941.

Abbot, T. (2001) "Social and Personality Development" Routledge, London (2001).

Altman, I. (1980) Children and the Environment. New York: Plenum Press.

Bell, S. (2002). Spatial cognition and scale: A child's perspective. Journal of Environmental Psychology, 22, 9-27.

Bell, S. (2006). Scale in children's experience with the environment. In C. Spencer, \& M. Blades (Eds.), Children and their environments: Learning, using and designing spaces (pp. 1325). Cambridge, MA: Cambridge University Press.

Bozdayi, A. M. 1988 Children In The Physical Environment An Aproach To Design For Children A Day Care Center Proposal In Beytepe. Ankara: Master Theses, Faculty of Architecture, METU. 
Clark, A. (2005). Talking and listening to children. In M. Dudek(Ed.), Childrens spaces (pp. 1-13). Oxford: Architectural Press.

Cohen, S., \&Trostle, S. (1990). Young children's preferences for school related physical environment setting characteristics. Environment and Behaviour, 22, 753-766.

Çukur D., Delice E. G., (2011). “Erken Çocukluk Döneminde Görsel Algı Gelişimine Uygun Mekân Tasarımı ", Aileve Toplum Eğitim-Kültür ve Araştırma Journal, pp.25-35.

Day, C. (1990). Places of the soul. London: The Aquarian Press.

Day, C. (2002). Spirit \& place. Oxford: Architectural Press.

Day, C., \&Midbjer, A. (2007). Environment and children: Passive lessons from the everyday environment (1st ed.). Amsterdam, NL and London, UK: Architectural Press.

Derr, V. (2002). Childrens sense of place in Northern New Mexico. Journal of Environmental Psychology, 22, 125-137.

Dudek, M. (2000). Kindergarten Architecture: Space for the Imagination. Second edition. London, UK: Spon Press.

Dudek, M. (2001). Building for Young Children: A Practical Guide to Planning, Designing and Building the Perfect Space. London, UK: National Early Years Network.

Dudek, M. (2008). A Design Manual Schools and Kindergartes. Berlin: BirkhauserVerlag A.G.

Dudek, M. (ed.). (2005). Children's Spaces. London, UK: Architectural Press.

FaberTaylor, A., \&Kuo, F. E. (2006). Is contact with nature important for healthy child development? State of the evidence. In C. Spencer, \& M. Blades (Eds.), Children and their environments: Learning, using, and designing spaces (pp. 124-140). Cambridge, MA: Cambridge University

Feldman, R. S. (2007). Child Development (4th ed.). Upper Saddle River, NJ: Pearson Prentice Hall.

Gaskins, S. (1999). Children's daily lives in a Mayan village: A case study of culturally constructed roles and activities. In A. Gon$\mathrm{cu}$ (Ed.), Children's engagement in the world: Socio-cultural perspectives (pp. 25-61). Cambridge: Cambridge University Press.

Gibson, J. J. (1986). The ecological approach to visual perception. Hillsdale, NJ: Lawrence Erlbaum. (Original work published 1979).

Gump, P.V. (1987). 'School and Classroom Environments.' In Stokols, D. and I. Altman, eds. Handbook of Environmental Psychology. New York: Wiley, 691-732.

Gür, Ö. Ş., Zorlu, T. (2002). Children Spaces. İstanbul: YemYayınları.

Gürkaynak, İ. (1988). “Çevresel Psikoloji: Doğası, Tarihçesi, Yöntemleri". Ankara Üniversitesi Eğitim Bilimleri Fakültesi Dergisi, 21(1)1-9.

Gustafson, P. (2001). Meanings of place: Everyday experience and theoretical conceptualizations. Journal of Environmental Psychology, 21, 5-16.

Guy, J. (2000) "The Culture of Design" SAGE Publication Ltd. London.

Guy, J. (2006) "From Visual Culture to Design Culture" Design Issues: Volume 22, Number 1 Winter, pp. 54-76.

Han R., Li, S. and Shi, J. (2008), The Territorial Prior-Residence Effect and Children's Behavior in Social Dilemmas, Environment and Behavior, October 22.

Hay, R. (1998). Sense of place in developmental context. Journal of Environmental Psychology, 18, 5-29.

Hosny, I., Anous,I (2015)"The impact of Interior Design in educational spaces for children with Autism", American International Journal of Research in Humanities, Arts and Social Sciences10(1), March May 2015, pp. 90-101.

Kimbel, L. (2011) "Rethinking Design Thinking: Part I"Volume 3, Issue 3,Taylor\& Francis Kostić, A., Stanković, D., Tanić, M., Nikolić, V. (2014) "REVITALIZATION PROCESS OF PRESCHOOL BUILDINGS"Architecture and Civil Engineering Vol. 12, No:3, 2014, pp. 243-252.

Kimbel, L. (2012) “Rethinking Design Thinking: Part II" Volume 4, Issue 2, 2012, Taylor \& Francis journal, pp.129-148.

Korpela, K. (2002). Childrens environments. In R. B. Bechtel, \&A. Churchman (Eds.), Handbook of environmental psychology (pp. 363-373). New York: Wiley.

Kounin, J. S., Sherman, L. W. (2001) School Environment as Behavior Setting. S. 145-151, New York: Journal of Educational Psychology.

Kyle, G. T., Mowen, A. J., \& Tarrant, M. (2004). Linking place with place meaning: An examination of the relationship between place motivation and place attachment. Journal of Environmental Psychology, 24, 439-454.

Lim M., Barton A. G., (2010) Exploring insideness in urban children's sense of place, Journal of Environmental Psychology 30, pp.328-337.

Margolin, V.\&Margolin S. "A "Social Model" of Design: Issues of Practice and Research"Design Issues: Volume 18, Number 4 Autumn 2002, pp. 24-30.

Maxwell, L. E. Home and School Density Effects on Elementary School Children The Role of Spatial Density Environment and Behavior, 35 (4) (2003), pp. 566-578.

Moore, G. T. (1987). The physical environment and cognitive development in child- care centres. In C. S. Weinstein \& T.G.

Moore, G.T. (2002). Designed environments for young children: Empirical findings and implications for planning and design. In M. Gallop \& J. McCormack (Eds.), Children and Young People's Environments (pp. 53-63). Dunedin, New Zealand: University of Otago, Children's Issues Centre.

Moore, G.T., Friendly, M, \& Rubin, M. (1995). Child Care by Design (video) Toronto: University of Toronto, Childcare Resource and Research Unit (available - Sydney: Environment, Behaviour and Society Research Group).

Moore, G.T., Lane, C.G., Hill, A.B., Cohen, U., \&McGinty, T. (1994). Recommendations for Child Care Centers(3rd rev. ed.). Milwaukee, USA: University of Wisconsin-Milwaukee, Center for Architecture and Urban Planning Research, Report R79-2.

Olds, A. R. (2001). Child care design guide. New York: McGraw Hill.

Press.Farver, J.A.M. (1999). Activity setting analysis: A model for examining the role of culture in development. In A. Goncu (Ed.), Children's engagement in the world: Socio-cultural perspectives (pp. 99-127). Cambridge: Cambridge University Press.

Proshansky, H. M. (1978) The city and self-identity, Environment and Behavior, 10, 147-169.

Proshansky, H. M. and Fabian, A. F. (1987) The development of place identity in the child. In: C. S. Weinstein \& T. G.

Proshansky, H. M., Fabian, A. F. and Kaminoff, R. (1983) Place 
identity: physical world socialization of the self, Journal of Environmental Psychology, 3, 57-83.

Proshansky, H. M., Fabian, A. F. and Kaminoff, R. (1995) Place identity: physical world socialization of the self, In: D. Canter (Ed.), Readings in Environmental Psychology. Given Places Meaning. London: Academic Press.

Proshansky, H. M., Nelson-Schulman, Y. and Kaminoff, R. (1979) The role of physical setting in life crisis experiences, In: C. D. Spielberger and I. G. Sarason (Eds.), Stress and Anxiety, Vol. 6. New York: Wiley.

Rapoport, A. (2000), "Culture, Architecture and Design”, Locke Science Publishing Company, Inc.

Read, M. A. (2007).Sense of Place in Child Care Environments. Early Childhood Education Journal, S. 387-392.

Rivlin, L.G. and M. Wolfe (1985). Institutional Settings in Children's Lives. New York: Wiley-Interscience.

Sanoff, H. ( 1993). Designing a responsive school environment. Children,,s Environments, IO(2), 140153.

Sanoff, H. (1991). Visual research methods in design. New York: Van Nostrand Reinhold.

Sanoff, H. (1995) Creating Environments for Young Children. Ohio: Bookmasters Inc.

Smith, A. B., Grima, G., Gaffney, M., \& Powell, K. (2000). Early childhood education: Literature review report to Ministry of Education. Dunedin: Children's Issues Centre.

Spencer, C., \& Blades, M. (2006). Children and their environments: Learning, using, and designing spaces. Cambridge, MA: Cambridge Unviersity Press.

Spodek, B. (1986). Today's kindergarten: Exploring its knowledge base, extending its curriculum. New York: Teachers College Press.

Stanković D., (2008)Space in the Function of Psychological Stability of a Child pp. 229-233, Architecture and Civil Engineering, Facta University, Serbia, Vol. 6, No 2.
Stankovic, D., Milojkovic A., Tanic M. (2006) Physical Environment Factors and Their Impact on the Cognitive Process and Social Behaviour of Children in the Preschool Facilities. FactaUniversitesi: Architecture and Civil Engineering, S. 51-57.

Stankovic, D., Stojic, J. (2007) Psycho-Developing Needs of Children and Spatial Features for Children's Stay. FactaUniversitesi : Architecture and Civil Engineering, S. 71-75.

Tezel, E. (1999) A Design Model for the Space Planning Child Care Centres.: Ph.D. Dissertation, Fine Arts Institute, Bilkent University Ankara.

Türe, E., KaraküçükS. A. (2011). "Study of education environments in terms of physical/spatial variables in regional primary boarding schools", Ankara University, Journal of Faculty of Educational Sciences, year:, vol: 44, no: 2, 165-197.

Uysal, F. (2006) A study on indoor and outdoor space organizations at preschool education centres, regarding the education theories. Master Theses, Gazi University, Ankara.

Vojislav, N., Aleksandar, K., Danica, S., Milan, T. (2013) Remodeling of the interior of preschool institutions in the context of improvement of ambient value and quality of space, Factauniversitatis - Architecture and Civil Engineering, Volume 11, Issue 3, pp. 211-220.

Weinstein, C.S., \& David, T.G. (Eds.) (1987). Spaces for Children: The Built Environment and Child Development. New York: Plenum.

Yalcin, M. (2011). Affects of the Physical Environment in the Preschool Education Spaces over Child Development and Psycho-Social Determinants Effecting Their Spatial Formation. Ph.D. Dissertation, Institute of Social Sciences, Hacettepe University, Ankara.

Yaneva, A. (2009) "Making the Social Hold: Towards an ActorNetwork Theory of Design"Design and Culture, Volume 1, Number 3, November 2009,Bloomsbury journal, pp. 273288(16). 